\title{
THE MISSIONARY NATURE OF THE CHURCH IN THE BOOK OF ACTS. AN EXEGETICAL AND THEOLOGICAL STUDY
}

\author{
Ph.D. Daniel AYUCH, \\ St. John of Damascus Institute of Theology, \\ University of Balamand, \\ E-mail: dayuch@gmail.com
}

\begin{abstract}
The Acts of the Apostles speaks often about the social work of the Church through recurring concepts such as koinonia, mercy, hospitality and philanthropy. This paper deals with the ways that the Book of Acts promotes harmony in conditions of diversity (such as religious, cultural, or political pluralism). Several texts will be compared and interpreted to draw a clear picture of the Church's call to serve the world and to witness Christian Faith in words and deeds. The world can be healed with the power of the Divine Word. This does not happen only by preaching and teaching, but also by acting and caring for the needed and the poor. The theological narrative of Acts shows how the Christian faith - the Way, as Luke likes to call it - grants a new understanding of reality and calls people to break the rules of worldly wisdom and to behave according to the wisdom of the Kingdom, where the principles of social relation are redefined through the lens of the Resurrection.
\end{abstract}

Keywords: Acts of the Apostles; social work; Church; mission, koinonia; Resurrection; community service; Diakonia; hospitality;

\section{INTRODUCTION}

With the Resurrection of Christ, something new happened in human history and in all creation. The possibility of restoring corrupted nature and giving back life to a rotten body has inspired very soon early Christian communities to do the same in their context, i.e., to give life again to a society overcome by the power of death and sickness.

Preaching the kerygma of Resurrection implies a change in society. Therefore, mission means acting and doing good deeds, as well. Missionaries are not only expected to teach, which is of course the basis and foundation of all their activities, but they are also expected to help people organize their new life and to express their faith in everyday work.

The second book of the Lucan diptych has the particularity of narrating the formation of the Church in a well-structured account that takes place in the East Mediterranean region. Saint Luke the Evangelist opted for writing two volumes, the first one deals with the revelation itself and with the foundation of faith, while the second deals with the apostles' and the people's witness to this faith. In this way, Luke wrote an etiology of the Christian faith. ${ }^{1}$ As a matter of fact, Luke follows the Old Testament pattern of TorahHistorical Books, where God also reveals his will and then the people witness to it among the nations. The main difference is shown in the eschatological aspect of the Lucan account.

${ }^{1}$ LÖNING, Geschichtswerk. I, 48. 
For him, these books contain the definite answer to God's promises in the Old Testament and to the people's expectations in the first century AD.

This paper deals with the ways that the Book of Acts promotes harmony in conditions of diversity (such as religious, cultural, or political pluralism). Several texts will be compared and interpreted to draw a clear picture of the Church's call to serve the world and to witness to the Christian Faith in words and deeds. There are three topics that show the concept of mission and social engagement in the Book of Acts and that are presented in this article: (a) Community Service, (b) Impartiality and (c) Hospitality.

The Book of Acts teaches that the world can be healed with the power of the Divine Word. This does not happen only by preaching and teaching, but also by acting and caring for the needy and the poor. The theological narrative of Acts draws within its lines new principles of social relation, which are redefined through the lens of the Resurrection.

\section{COMMUNITY SERVICE}

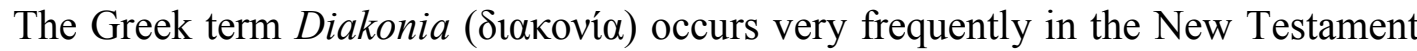
(32 times). The Pauline letters use it the most, namely 24 times. After Paul follows Luke, who uses it 8 times in Acts and one in the Gospel. Diakonia does not only mean service or ministry, but particularly the charitable service, with the idea of giving aid and support to the needy ones, this is why the title of this paragraph is Community Service. Sometimes it can also connote the service of God as an office or ministry, which is always related to the community. Preaching the Word is a service as much as attending the tables of the poor is.

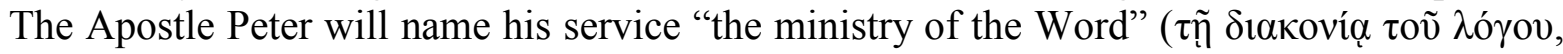

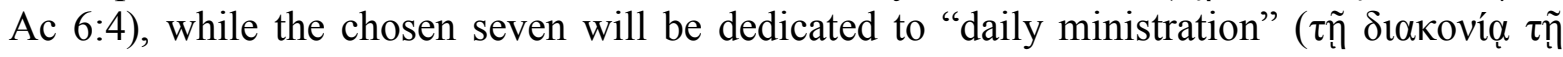
$\kappa \alpha \theta \eta \mu \varepsilon \rho v \eta n ̃$, Ac 6:1). There is no dichotomy between both services. The seven men are not chosen because of their capacity to attend tables but because of their reputation, their inspiration by the Holy Spirit and their wisdom (Ac 6:3).

The concept of Diakonia is not only present where the term appears. For Saint Luke, the first Christians practiced charitable relief on such a large scale that there was no one in need among them (see, for instance, Ac 4:34). The Apostles themselves took care of the sick ones and even raised the dead in the name of social service or Diakonia. In the coming two paragraphs, we shall see what is meant with Diakonia in the sense of relief for the poor and the sick.

\subsection{Diakonia for the poor}

Because of Pentecost and the persuasive speech that Saint Peter gave in Jerusalem about the Resurrection of Jesus Christ, thousands of people started to change their behavior. The first two summaries of Christian community life in Acts (2:41-47 and 4:32-35) give the impression that there were not only an important number of rich people, who were ready to sell their possessions, but also poor Christians were there to receive the donations.

The summaries show that first \{Do you mean the adverb firstly or the adjective 'early\} Christians tried to level social differences among them and to live all together as brothers and sisters who care for each other. As a matter of fact, someone who had sold his properties and distributed the proceeds among the hungry has quickly enough become as poor as they. Christians live in full trust of God's providence. As the Lord Jesus said: "Observe how the lilies of the field grow; they do not toil nor do they spin, yet I say to you that even Solomon in all his glory did not clothe himself like one of these" (Mt 6:28-29).

The verb "to distribute" ( $\delta 1 \alpha \mu \varepsilon \rho i \zeta \omega)$ is quite an important term in this context. On the one hand, the tongues of fire "were distributed" among the community gathered in the 
house (2:3). On the other hand, the believers distributed their possessions and goods for the sake of helping their fellow-Christians (2:45). As a response to God's generous distribution of eschatological gifts, the members of the Church care to provide the ones in need with earthly goods. ${ }^{2}$ Christian detachment of valuable possessions is directly related to their new world vision, in which human beings have restored their value, for God's intervention in history has given them a tangible hope for salvation.

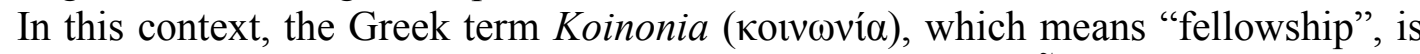

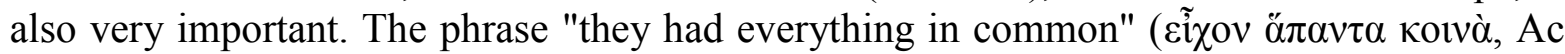
2:44) finds no parallel in either the Old or the New Testament. The expression is based on Hellenistic cultural backgrounds and represents Greek ideals that make more comprehensible the early Church experiences after Pentecost. In classic Greek writings, this formula can be used with mainly three different purposes: (1) as a principle for an ideal state, (2) as a myth of a past golden age, (3) as a principle of friendship. However, the purpose in Acts is eschatologically oriented. As Dupont notes, Luke prefers to call the members of the community "believers" (oi $\pi 1 \sigma \tau \varepsilon v ́ o v \tau \varepsilon \zeta$, Ac 2:44), instead of using the typical Hellenistic terms "friends" or "brethren". ${ }^{3}$ Luke sees a deep relationship between social behavior and the work of the Spirit on the day of Pentecost. Therefore, he envisages the fellowship of goods as a result of the eschatologically fulfilled hope of Israel. This becomes even clearer when one notices the explicit use of Old Testament terminology and theology. Klauck summarizes the Old Testament influence in three essential motifs: ${ }^{4}(1)$ the expression "one heart and one

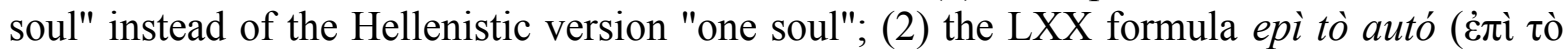

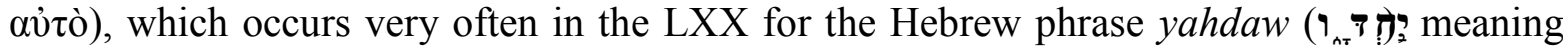
together; (3) and above all the theological allusion to Dt 15:4 in the expression "for there was not a needy person among them" of Ac 4:34.

\subsection{Diakonia for the sick}

Already in the second summary there is an allusion to the Apostles' gift for healing the sick (Ac 4:33) and the third one is clearly more concentrated on this topic (Ac 5:12.1516). As a matter of fact, the ministry of the Word and the ministry to the poor is finally completed by the ministry to the sick. This activity is considered as charitable relief, as well, and belongs to the "good deeds" ( $\kappa \alpha \lambda \grave{\alpha}$ है $\gamma \gamma \alpha$, Matt. 5:16; Jn 10:32; 1Tim 5:25; Mk 14:6) of Jewish and now Christian pietism, which is so frequently quoted in the New Testament.

Particularly interesting for this title are two sets of parallel narratives that show the healing power of the Church at the hand of Saint Peter and Paul. The first set consists of two healing miracles: the lame man of the Temple (Ac 3:1-10) and the cripple man of Lystra (Ac 14:8-18). No doubt that these two scenes represent the inclusion of marginalized people in the community of the Church. However, they also teach the caring love of the Apostles that do not only teach and preach but also see the immediate need of these two men and intervene for releasing them of their pains. Luke cares to underline the importance of faith in both scenes. Saint Paul heals the sick man when he perceived that he had faith to be "saved". So does Peter at the Beautiful Gate of the Temple, when he fixed his gaze upon the beggar and he saw, as Paul did, the faith in his heart (Ac 3:4).

Besides, Acts tells two narratives about the raising of dead: The first is the young woman Tabitha of Joppa, who was healed by Saint Peter and the second is the young man Eutychus of Troas, healed by Saint Paul (Ac 9:36-43 and 20:7-12). Tabitha was restored

\footnotetext{
${ }^{2}$ Cf. AYUCH, Handeln. 85.

${ }^{3}$ Cf. DupOnT, Études, 519.

${ }^{4}$ Vgl. KLAUCK, ,Gütergemeinschaft", 74 § 3.
} 
back to life to continue with her good work that helped widows and needed people, while Eutychus came back to life to learn to listen carefully to the Word of God. Two examples of pastoral care performed by the Princes of the Apostles showing the force of the missionary church. These scenes are only examples within the Book of Acts which is plenty of wonders performed by the Apostles in Jerusalem, Judea, Samaria and the Hellenistic World while they traveled around preaching the kerygma of the Resurrection. We can mention a few: The Apostles heal many in Jerusalem (5:15-16); Philip heals many in Samaria (8:5-8); Peter heals Aeneas at Lydda (9:32-35) and Paul heals a slave girl at Philippi (16:16-18).

\section{IMPARTIALITY}

After Pentecost, the Church takes a universal character and is open to every human being in the world. Saint Paul says in Galatians: "There is neither Jew nor Greek, there is neither slave nor free man, there is neither male nor female; for you are all one in Christ Jesus" (3:28). As a matter of fact, Jesus behaved and taught without any favoritism. He addressed the weaker and the lower social strata. He took care of marginalized sick people as well as of foreigners and Gentiles. Saint Paul uses in his letters for this teaching the term Partiality/Favoritism ( $\pi \rho \circ \sigma \omega \pi \circ \lambda \eta \mu \psi i ́ \alpha$, see Rom 2:11; Eph 6:9; Col 3:25; also in Jam 2:1). Acts of the Apostles narrates in several opportunities some exemplary stories with the purpose of teaching the principle of impartiality and tolerance for the coming generations. For Saint Luke, Christians are a new category of people, who behave following the Lord's words and deeds. For them, no worldly ethos has authority, since as of now the ethos of the Kingdom rules. Therefore, no discrimination between human beings can be accepted.

\subsection{No Preference for Cultural Origins}

The first episode one can mention from Acts is, undoubtedly, the incident with the widows and the election of the Seven (Act 6:1-7). This text witnesses how Christians from Hellenistic origins complained that local Aramaic speaking Christians neglected their widows in daily services. There was a practice of favoritism that broke the communion of goods established after Pentecost. In the account, Luke does not describe in detail the conflict causes because he focuses on showing the community's ability to find a solution. With the election of the Seven for serving the tables without favoritism the unity of the community is restored: "The whole assembly approved this proposal" (6:5). Solutions in the Early Church are not based on discrimination but on tolerance and impartiality. Thus, this account is above all an edifying story laying emphasis on the need of the community to avoid any kind of unfair treatment of its members. ${ }^{5}$ The Christian community is expected to be open to everyone without distinction.

Once the conflict is overcome and solidarity is restored, the word of God keeps on growing and the number of disciples multiplies: "And the word of God kept on spreading; and the number of the disciples continued to increase greatly in Jerusalem, and a great many of the priests were becoming obedient to the faith" (6:7). The message is of vast importance: The unity of the Church is an essential part of Christian mission. According to Luke the Church is not only expected to coordinate and deliver the services of preaching, and helping the poor, but all this must happen in harmony and without favoritisms among their members.

\subsection{No Preference for Religious Origins}

The author ad Theophilum dedicates several pericopes to the question whether the Church should show a certain preference to those who come from Judaism to the detriment

\footnotetext{
${ }^{5}$ TARAZI, Old Testament 1, 22-25.
} 
of those coming from gentility. One of the most prominent readings that deal with this question is the narrative of the so-called Apostolic Council in Acts 15:1-29. The communitarian aspect of this episode is clear and has several indicators. It is "the Church", who sends Paul and his companion to Jerusalem; it is again "the Church" (v. 4) of Jerusalem, who receives the Antiochian delegation. It is "the multitude" who listens to Peter, Paul and James (v. 12) and the Apostles start their speeches and the letter with the word "Brethren" (vv. 7.13.23). Moreover, "Brethren" is used very frequently in this chapter to refer to the members of the community ( 9 times: vv. 1.3.7.13.22.23*2.32.33). As a result of the council, there is a meeting in Antioch and they rejoice with the letter message (v. 33), which clearly refuses to charge the Church with a "great burden" (v. 28), a term that in the context of the scene implies nothing more than to impose circumcision and the observation of the Law as practiced by the Jews.

In other words, the decision of the Jerusalem assembly affirms that Gentile Christians are supposed to abandon their former practices of idolatry, as much as Jewish Christians are expected to leave their former practices of Judaism. Christianity is neither a new Gentile religion, nor a Jewish sect. Christianity has been founded by the teachings of Jesus Christ and the seal of the Holy Spirit at Pentecost (Acts 2). Christians are taught to leave behind their former religious practices and to follow a new life of "divine service" ( $\lambda \alpha \tau \rho \varepsilon i ́ \alpha)$ according to the teachings of the Lord and His Apostles.

Luke develops in one chapter of meetings and discourses, what had been the key question among the Christian communities living on the east coast of the Mediterranean basin. Paul dedicates chapters of his letters to this issue, particularly in Galatians and Romans and he reaches similar results. ${ }^{6}$ The Lucan text (see vv. 2.7a) shows affinity with other narratives in the Gospels and with some allusions Paul makes to the dissentions and debates caused by some Christians influenced by certain Jewish teachings. Let us mention for instance Jn 9 or Mt 23; Gal 3 or 1Tim 1:6-11. The Synoptic Gospels focus frequently on the issue of salvation for the Jews and the Nations, for all mankind. Let us think, for instance, about the miracle stories in Mt 8-9 and all their parallels in Luke and Mark. Healing and preaching go to every human being, no matter what religious background he or she comes from. In Acts 15 Luke chooses the narrative framework of an apostolic assembly to affirm that there is a consensus among Christians regarding this issue.

Having said so, the letter issued by the Jerusalem assembly is to be seen not as a list of prohibitions but as a list of recommendations. Letters with moral recommendations were not unusual in early Judaism. ${ }^{7}$ The four recommendations given by the Apostles are the general rules of Jewish behavior among the nations; James knows them and has already mentioned them in his discourse (Ac 15:20). In a way, they seem to be a slight concession to the Jewish parties who were advocates of circumcision. However, what this letter really teaches is that from now on the Christian communities follow neither the ethos of the Jews ('no' to circumcision), nor the one of the nations ('no' to idolatry); they are bound to live according to Jesus' teachings.

Once in Antioch, the Apostles convene the community and deliver the letter that produces joy among those gathered (v. 31). The act of "rejoicing" ( $\chi \alpha i ́ p \omega)$ is the Lucan sign for the inception of eschatological time, the human answer when they witness to the fulfillment of God's plan. Barnabas and Paul have already caused great joy in the communities of Phoenicia and Samaria, when they proclaimed the conversion of the Gentiles

\footnotetext{
${ }^{6}$ See AYUCH, "Roots", 147-165.

${ }^{7}$ LANGNER, Evangelio. 354.
} 


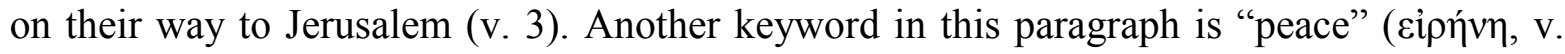
33). In the Lucan diptych, peace and joy are two indicators of the eschatological times. They remind the readers of the birth of Jesus (Lk 2:10-14) and of the Lord's entry into Jerusalem (Luke 19:37-38). Readers understand that God begins to fulfill his plan with the Gentiles, which is their integration into the community of salvation.

Both texts, Ac 6:1-7 and 15:1-29, show that the expanding and mission oriented Church does not know either discrimination of ethnia, nor of religions. God's call to be part of His people is open to every single human being. Let us think of the two cultural parties that constitute the primeval community in Jerusalem or the permanent acceptance of both Jews and Nations (other than Jews) in Acts 15. Both paragraphs show that the Church cannot endorse a secular or religious culture to be used as the exclusive basis of her kerygma, since the Church embraces and changes any human background with the power of Divine revelation.

\section{HOSPITALITY}

A community that strengthens the weak and feeds the hungry, a community that keeps its door open to every human being, no matter their language, religion or nation, such a community cannot but show a great sense of welcoming hospitality to everyone.

The New Testament registers two relevant words related to this topic: the noun

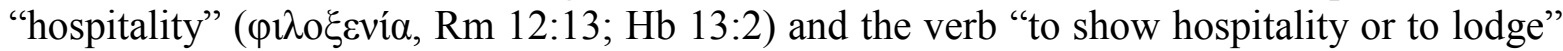
( $\xi \varepsilon v o \delta o \chi \varepsilon \dot{\varepsilon} \omega, 1$ Tim 5:10). In these three texts the authors foster the practice of offering shelter and food to the strangers. In Romans, Saint Paul argues that Abraham and Sarah have entertained angels without knowing it because they were hospitable.

The Book of Acts does not have matches for these two terms. However, there are plenty of pericopes that encourage hospitality as it was practiced in the early Church. Without hospitality St Paul would have never been able to move between towns, regions and even continents.

Luke tells that this process of changing places and meeting new people and cultures has not always been an easy task for the first missions of the Apostles. Saint Peter, for instance, needed a vision and the initiative of Cornelius' emissaries to be able to move from the house of Simon the Tanner, who was a Jew, to the house of Cornelius, a Roman military leader (see Ac 9:43 - 10:48). When the brethren in Jerusalem knew that Peter entered a Gentile house and that his Kerygma was accepted in the house, they took issue with him. They were afraid of losing their identity and being consumed by the splendor of heathendom. They had forgotten that it is not with their own will and words that they preach the Word of God but with the Holy Spirit's. Worldly speaking, the Church is small and weak and seems to be like a lamb among wolves. However, their members know that they are strong in their faith and have confidence to the Lord and his Holy Spirit.

Hospitality can be seen in many paragraphs of Acts. In the house of Mary, the mother of John Mark, there were many Christians gathered together praying when Peter came to them to find a shelter after being liberated from prison with the help of an angel (12:11-14). Lydia the seller of purple fabrics was the one who opened the doors of Philippi to Paul by accepting not only his preaching but also by urging him to stay at her place: "If you have judged me to be faithful to the Lord, come into my house and stay," said Lydia to Paul and Silas in Acts 16:15. Let us think also of Aquila and Priscilla in Corinth (Ac 18:2.18). Jason of Thessalonica was even risking his own life when he received the Apostle in his house (Ac 17:5-7). 
Hospitality happens because of this friendly disposition toward people that Christians have, because of philanthropy, a term present only once in Acts 28:2 to praise, not the members of the Church, but the natives of Malta, who cared for Paul and his companions after they shipwrecked. It is worth mentioning here that Christians practice an even higher virtue, the greatest of all, as Paul says in 1Cor 13, namely neighborly love. Neighborly love is one of the highest virtues in Christianity. However, this study is dedicated to study and analyze specific and particular practices that emanate from those who cultivate Christian virtues.

For a missionary church there is no land, no city, and no country that cannot be invited to be part of the people of God. Missionaries are called to move everywhere and to give witness in every place and under any condition. No land is the land of the elected ones and no land is the land of barbarians and sinners, as the Psalter says: "The earth is the Lord's, and all it contains. The world, and those who dwell in it" (24:1).

\section{CONCLUSIONS}

Acts witnesses how hard the Apostles worked to deliver effectively the teachings of the Lord. They preached, they healed and the engaged for the sake of the neighbor. They supported persecution, prison, pain and even death to help the others. From the Book of Acts the reader understands that missionary activity is not a privilege but a ministry, a service in the sense of the Greek word Diakonia. One understands that the Church in this world has the task to serve humankind without any distinction.

The evangelization plan given by the Risen Lord in Acts 1:8 is perfectly fulfilled in the final verses of the book (28:30-31): The Apostles have witnessed the Resurrection in Jerusalem, Judea, Samaria and, with Saint Paul in Rome, in the "remotest part of the earth." On the one hand, we reach the end of an era in which Paul, the last of the witnesses directly sent by the Risen Lord, concludes his mission's odyssey from Jerusalem, the city of the first assembly of the true Israel, to Rome, the center of the vast and fertile world of the Gentiles. On the other hand, modern readers feel disappointed by the Lucan ending, because they expect a conclusion to the biography of Paul. However, the readers should consider that neither in the case of Peter, nor in the case of any other Apostle, does Luke offer a conclusion to their lives. It is the path of the exalted Christ, the definitive carrier of salvation for all nations, that has been traced in Acts. His witnesses come in and go out of the book pages according to the demands of proclamation.

The end of Acts (verses 30-31) presents the Christian message with its untamed power to expand all over the world. When the reader closes this book, the personal fate of Paul is overshadowed by this open end of the triumph of the Gospel above any powerful opposition. If one reads the Acts of the Apostles as being the acts on the proclamation of the Gospel, one understands the leading role of the Gospel in the Lucan narrative and comprehends the end of the book as a triumphant one.

Proclaiming the Gospel conveys to people a new understanding of reality that breaks the rules of worldly wisdom and leads to the wisdom of the Kingdom, where the principles of social relation are redefined with the eyes of faith. When the new believers experience the visit of the Lord in their lives and in their hearts, they feel the liberation power of the Gospel and are motivated to build a new life based on the civilization of love. 


\section{BIBLIOGRAPHY:}

[1] AYUCH, D.A. "Rich Roots feed the Branches. The Community of Believers in the Pauline Similitude of the Olive Tree." In: MASSOUH, G. (ed), Face and Grace. A Festschirift to Archbishop George Khodr. Beirut: Nour Press, 2007, 147-165 (ARABIC).

[2] AYUCH, D.A. Sozialgerechtes Handeln als Ausdruck einer eschatologischen Vision. Zum Zusammenhang von Offenbarungswissen und Sozialethik in den lukanischen Schlüsselreden (MthA 54), Altenberge: Oros Verlag, 1998

[3] BIBLE WORKS. Bible Works, Ver. 9, Bible Works for Windows, Hermeneutika Computer Bible Research Software, 2011, Released for Windows Vista/7, DVDs.

[4] DUPONT, J. Études sur les Actes des Apôtres (LeDiv 45), Paris, 1967.

[5] KLAUCK, H.J. „Gütergemeinschaft in der klassischen Antike, in Qumran und im Neuen Testament", in: RQum XI (1982), 47-79.

[6] LANGNER, C. Evangelio de Lucas. Hechos de los Apóstoles. Biblioteca Bíblica Básica 16. Estella: Verbo Divino, 2008.

[7] LÖNING, K. Das Geschichtswerk des Lukas. Band I: Israels Hoffnung und Gottes Geheimnisse. Urban Taschenbücher 455. Stuttgart: Kohlhammer, 1997.

[8] Tarazi, P.N. The Old Testament 1. An Introduction. Historical Traditions, Crestwood (NY) 22003. 